\title{
Heritage Today: The Art of Transforming What We Received from the Past
}

\author{
Fernando Pérez Oyarzun \\ Faculty of Architecture, Design and Urban Studies, Pontificia Universidad Católica de Chile, Santiago, Chile \\ Email:fperez@uc.cl
}

\begin{abstract}
The paper aims at highlighting the new reality of urban and architectural heritage. It maintains that the current public claim for heritage protection radically diverges from the original endeavour of protecting national monuments. The significant expansion of heritage goods and the involvement of citizen movements in the decisions about them are two of the most visible aspects of this change. The paper suggests that a renovated idea of heritage is currently needed. This should take into consideration aspects such as its economic value and its connection to the quality of daily life. Defending that urban preservation has turned to be part of planning, the paper foregrounds some of the problems of keeping it as a separate legal and cultural domain. This is exemplified by Latin American reality and some specific cases from Chile. Finally it highlights the positive role of transformation and adaptation in the preservation of heritage.
\end{abstract}

KEYWORDS heritage, urban heritage, heritage challenges, heritage transformation, Latin American heritage

Received July 5, 2017; accepted July 26, 2017.

\section{Cultural Heritage: The Challenges of a New Status}

Sometimes changes occur in front of us but we are not fully capable of perceiving them. This happens, in part, because of the slow displacement of historic phenomena. As happens with the watch hands, we don't perceive each one of their movements but, after a span of time, we see that they have moved to a new position. Heritage is currently the dominant concept to designate what during the $19^{\text {th }}$ and early $20^{\text {th }}$ centuries was usually called monument. However, significant changes are hidden behind this designation change.

Probably the most visible novelty brought by the term 'heritage' is the expansion of its meaning. As Francoise Choay (2007) has underlined, heritage is a concept significantly wider than that of monument and refers to an ample universe, going from gastronomy to oral traditions, from religious celebrations to urban areas. This brings with it technical, social and institutional consequences: 'The triple expansion typological, chronological and geographic of the heritage goods has been accompanied by the exponential growing of its public.' (Choay 2007, 10)
This process, apparently of a purely quantitative nature, involves significant qualitative consequences. The implication of a wider number of stakeholders in the political arena related to the protection and management of heritage is undoubtedly one of them. Thus, the concern about heritage, usually confined to the field of expert knowledge, has been obliged to take into consideration lay knowledge. Thus heritage preservation has turned part of the political agenda. Being an international trend, this has frequently led to public debates on the subject. Conflicts about private property rights and urban heritage, or about the economic resources involved in restoration and conservation have been frequently under discussion. From a theoretical point of view, one can ask how far is it possible to transform heritage to integrate it into something that respond to cultural, social and economical needs; how to endow past with the capacity of enriching present reality.

Landscape is one of those recently incorporated heritage fields. It currently appears as an emergent and key concept for the understanding and management of cities and territories. Francois Walter (2004) has highlighted how landscape and natural elements have been culturally charged with national values. This leads us to the 
tight the link between the protection of monuments and the development of national identity. When Auguste Rodin (1914) published Les Cathédrales de France he was pointing to their meaning for French identity and culture. This same idea is still perceivable in the naming of some of the institutions that take care of heritage protection. This happens in Chile, as in many other countries, where the Consejo de Monumentos Nacionales (National Council of Monuments) created in 1925, still keeps its original name. Both the traditional idea of monument and that of national values are clearly perceivable in its designation. The already described new perception of heritage occurs simultaneously with the emergency of a certain crises-or at least questioning - of the idea of nationality. The latter is evident in the current phenomenon of globalisation and in the thinking of philosophers such as Hannah Arendt (Beiner 2002, 44-62). How to approach, therefore, a new idea of heritage in a globalised world? That seems to appear as a key question. The signing of a World Heritage Convention, in the context of the 1972 UNESCO meeting in Paris, responds, at least in part, to those challenges. The convention confronts them in two ways: firstly, recognising both natural and cultural sites and secondly, promoting their protection at a world scale.

The idea of affirming and defending self-identity has become central in defining heritage today (Graham and Howard 2008). It is true that identity is currently not only associated to national values, but even managed at local and community scales. However, in approaching a renovated idea of heritage other dimensions should be considered. In the first place, the fact that heritage implies always an economic dimension is frequently forgotten. The destruction of built heritage means inevitably an economic loss. Complementarily, its recovery or protection needs significant investments. This is evident in cases when natural disasters or war events provoke heritage damages.

The connections of heritage with material culture are not always sufficiently considered. As a consequence, the significance of heritage for daily life is put in value as it should. When great disasters occur, as happens with earthquakes in Chile and other Latin American countries, significant portions of the population are affected. On those occasions, people lose not only their premises and economic goods, already difficult to recuperate, but also the material support of their way of living. That is the case of rural communities in which their humble adobe residences are eventually replaced by emergency solutions. Those totally alter their daily uses, producing dramatic changes in their lives. This perspective gives heritage protection a new social and political meaning.

It is then legitimate to question us about the contemporary meaning of heritage protection. If heritage is usually associated with the idea of value, what are those values that define it as such? That needs to be permanently reconsidered. It is ironic to verify that criteria such as 'typical' or 'picturesque' are still those that decide, at least in legal terms, about the protection of urban areas. That has been the case in Chile where the National Comptroller of the Republic has employed them to decide on legal conflicts about heritage protection. That could mean, for instance, that keeping a façade to guarantee the scenography condition of an urban setting, allows someone to totally transform the uses and interiors of a property.

In this new scenario it is finally the power of regulations, which finally decides on the heritage quality recognised to certain goods. Thus, heritage is identified as those places or buildings that the society has decided to protect from destruction. As a course delivered by the Open University at the UK puts it, 'It is clear that these sites are defined as heritage by the sheer fact that they have been classified as such through inclusion on a heritage register.'

If heritage meaning has so radically expanded, to connect with social life, the protection strategies must be put under careful consideration. Does restoration mean a return to an original idealistic condition, perhaps an illusionistic one? Is that even possible? Or, on the contrary, a certain degree of transformation is needed to keep heritage truly alive? Those seem to be key questions, not only to conceptualise the problem in a proper way, but also to implement effective and meaningful public policies.

\section{Heritage and Urban Development}

The expanded condition of heritage has brought with its significant challenges for planning. The multiplication of protected buildings, public spaces and urban areas have radically increased the links - and eventually the conflicts- between heritage and urban planning. While monuments remained a rather small set of pieces, they could be safeguarded by special regulations within a secluded legal domain, ruled by independent authorities. This could not be kept any more when that protected universe exploded, affecting significant urban areas. The most immediate consequence of that was the collision of regulations and authorities competences. The increasing number of committees, councils and agencies related to heritage, at different geographic scales, makes it very difficult to coordinate the administrative implications of heritage 
protection and management. On top of that, monuments councils, or institutions of their kind, received huge pressures, due to the obligation to administrate and regulate an increasing portion of the urban surface.

Those institutional problems appear all along Latin America and are well illustrated by some competences conflicts occurred in Chile. The Consejo de Monumentos Nacionales (National Monuments Council) sought to regulate the urban conditions of urban areas, designated as Typical Zones, to guarantee a better protection for them, including building height limitation. This decision collided with competences of the planning authorities of the Ministry of Housing and Urbanism. The conflict had to be arbitrated by General Comptroller of the Republic, which decided in favour of the Ministry. Building height was thus considered as pertaining to planning regulations, and subsequently excluded from conservation policies and competences. Conflicts between planning and heritage protection authorities, but also between central and local organisms, are currently turning more than frequent in Latin America.

The situation appears even more complicated in Chile, where two parallel ways to protect heritage have been implemented. They are the Law of National Monuments and the municipal regulation plans. Both refer to architectural pieces and urban areas. They differ in the classification of protected goods, in the permanency of the given protection and on the authorities that need to be addressed in case of interventions. In the first case it is the Council of National Monuments; in the second, the municipal authorities. All this causes not only the difficult coexistence of different regulations, but that of buildings and urban places protected by different laws, located in the same urban zone but under the jurisdiction of different authorities.

Both the National Monuments Council and planning tools such as the communal regulatory plan need to be updated in order to cope with a contemporary view of heritage. In the first case, the expanded idea of heritage needs to be taken into consideration. The idea of monument and that of the picturesque, lying in the origin of the institution, are not sufficient to face the social and cultural forms assumed by heritage today. In the case of regulatory plans, they seek to establish limits to building activity, including the protection of buildings or urban areas. But they are not able to promote urban development by themselves. Development plans, more oriented towards urban management, have increased their relative importance.

However, new signs within the field of urban planning allow us to think about a renovated understanding of heritage, which is slowly emerging in Chile. In 2014, a
National Policy on Urban Development was promulgated. This included a specific chapter on identity and heritage. The latter was defined as a social good and, as such, included in a more integral view about urban development. Thus, despite that such policy is a general overview on urban issues, coexisting with formerly created institutions and regulations, it supposes a clear orientation towards a new inclusion of culture in urban development.

Protected heritage has currently turned into a key element in urban development. Today it is not convenient to seclude it as a separate realm. Heritage should be an acting part of urban development, providing it with a new cultural dimension and a historic continuity. Perhaps it is symptomatic that the contribution of UNESCO to the Habitat III Conference was called Culture Urban Future: Global Report on Culture for Sustainable Urban Development (UNESCO 2016). The significance of endowing a sustainable urban development with a cultural dimension asks for a new attitude, which would be able to connect both realms.

Another element that has to be taken into account is the social dimension that heritage preservation has increasingly acquired during the last decades. What are ultimately the reasons behind that interest of urban communities in heritage? Those attitudes seem to have become a steady tendency in the great majority of Latin American countries. Multiple forms of associations have been involved in the defence of neighbourhoods, public spaces or buildings. They have even claimed to be included in the official organisms in charge of taking care of urban heritage.

The case of Matta-Viel Typical Zone in Santiago de Chile provides us some clues to clarify the nature of this phenomenon. In 2008, a delegation of inhabitants of this neighbourhood located in Santiago's central-southern area, asked the Cultural Heritage Centre of the Catholic University to support them in presenting an application to the Council of National Monuments, in order to be listed as a Typical Zone receiving, therefore, official protection for the area. Matta-Viel exhibited a traditional urban fabric. A variety of typologies, from popular houses to early $20^{\text {th }}$ century facilities and housing complexes were part of it. The area had naturally evolved allowing all these different typologies to live together, producing a characteristic and lively urban environment (Figure 1).

The community representatives argued that there were both architectural and historical reasons to achieve the requested protection. They had collected information on those issues to value their claim. In the area there were a number of buildings designed by Manuel Cifuentes, who was the first graduated in architecture at the Universidad 

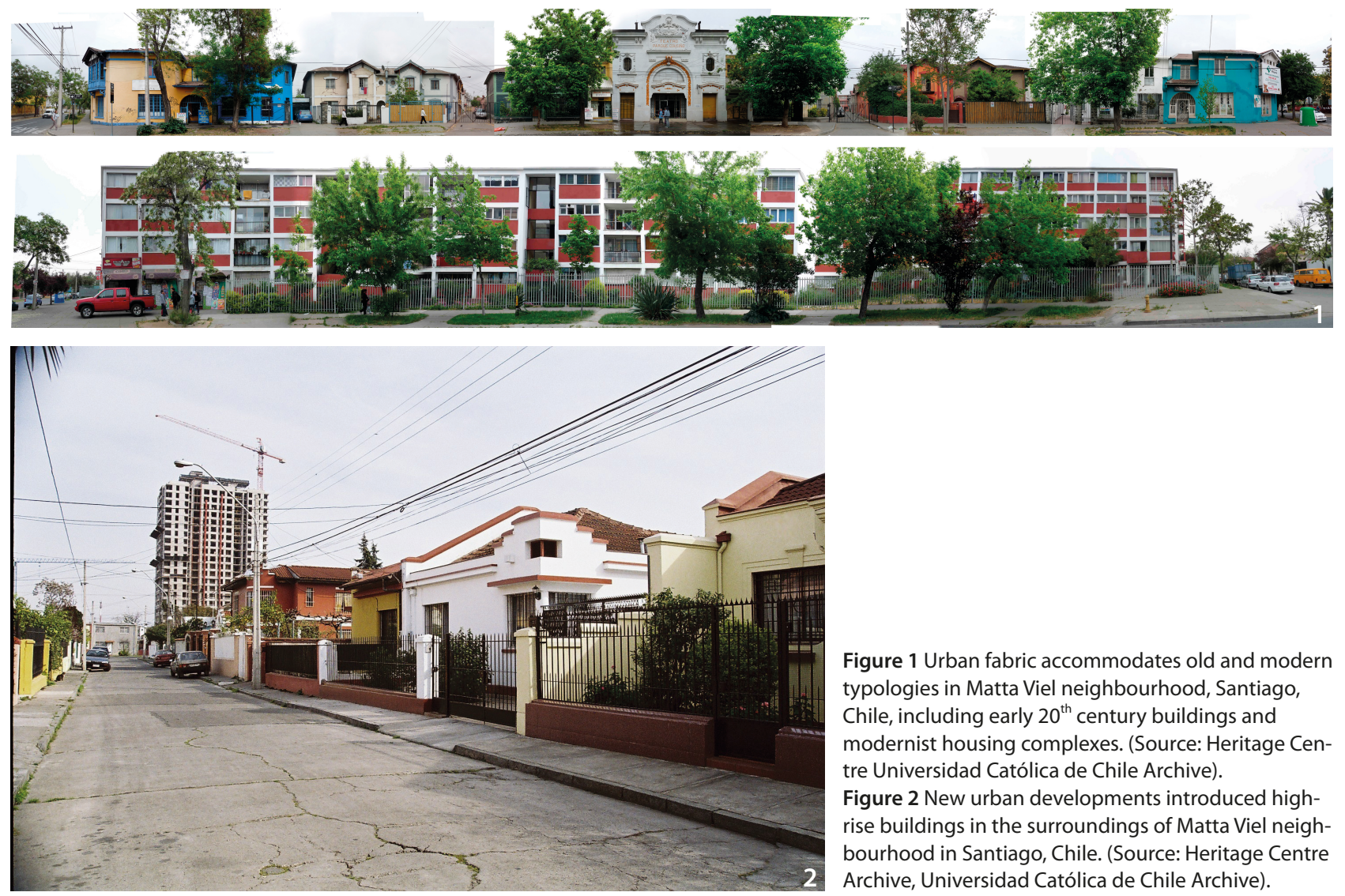

Figure 1 Urban fabric accommodates old and modern typologies in Matta Viel neighbourhood, Santiago, Chile, including early $20^{\text {th }}$ century buildings and modernist housing complexes. (Source: Heritage Centre Universidad Católica de Chile Archive).

Figure $2 \mathrm{New}$ urban developments introduced highrise buildings in the surroundings of Matta Viel neighbourhood in Santiago, Chile. (Source: Heritage Centre Archive, Universidad Católica de Chile Archive).

Católica de Chile, in 1906. With the institutional support of the Centre, the application was finally accepted. After that, with the support of public funds, the Centre assumed the responsibility of elaborating specific regulations for the area. This included surveying each street façade, as well as organising workshops and meetings with the community. What emerged from those experiences was the conviction that the true reason that had put the community in motion had been the threats of new urban developments, including high-rise towers, in the area (Figure 2). Thus, in fact they were using the National Monuments Law as a planning tool, something for which it had not been conceived. People were less interested in urban history or even in cultural identity, than in their own way of life. The declaration of Typical Zone has given way to a number of social and cultural initiatives concerning not only the area but, widely, also the urban heritage ${ }^{1}$.

\section{Transformation as a Strategy for Preservation}

The main intention of the precursors in monuments preservation was preventing those monuments to be destructed, as a consequence of the advancement of the Industrial
Revolution. Such were the intentions held by Mérimée or Rodin in France and Pugin or Ruskin in England. The preservation criteria put into practice to preserve or recuperate those monuments were subject of discussion from the beginnings. It is a well-known fact that Ruskin and Morris valued the traces left by time upon buildings, while Viollet le Duc preferred to complete them, seeking to bring them to a supposedly ideal stylistic condition. The same discussion has been prolonged over time. What should be the moment, towards which a restored building should return to? What previous interventions would be eliminated and which of them considered part of their historical evolution? A possible way to confront those questions is to accept that preservation is inevitably attached to transformation and, probably, adaptation to new historical circumstances is a decisive factor in preserving them as living cultural goods.

The case of La Moneda, the current Chilean presidential palace, provides a good example on how multiple and even radical transformations have allowed it to survive as one of the most significant architectural pieces of the city of Santiago. La Moneda was designed and built by the Italian Architect Gioacchino Toesca during the two last decades of the $18^{\text {th }}$ century and was intended to be the 

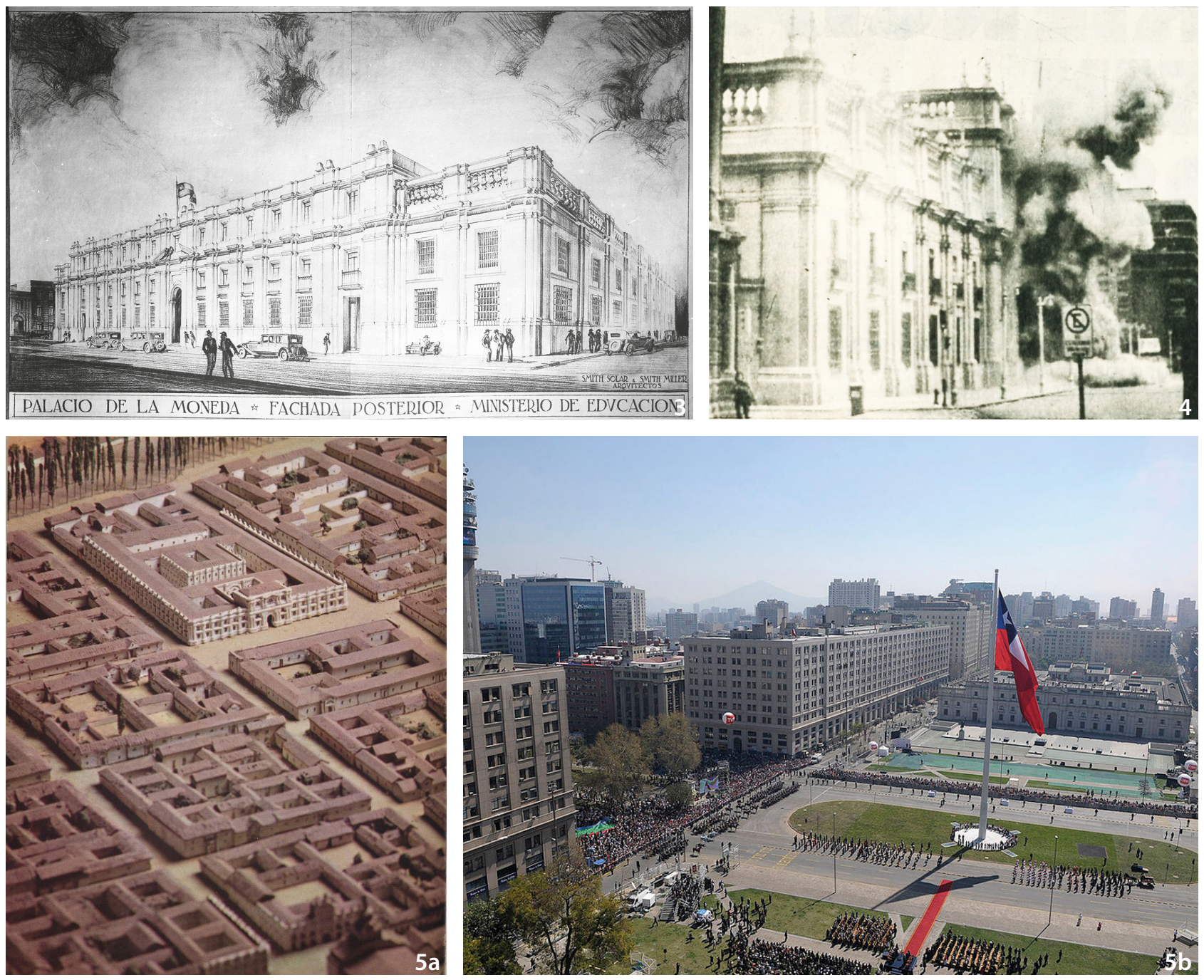

Figure 3 Josué Smith Solar and José Smith Miller, new southern façade project for La Moneda Palace, Santiago, Chile c. 1930. (Source: Dirección de Arquitectura, Ministerio de Obras Públicas).

Figure 4 La Moneda Palace destroyed by the Air Force bombing in September 1973. (Source: http://historiapolitica.bcn.cl/ hitos_periodo/ver_imagen?id=/JPG/9879899b59c576808adc84087e928318/ercilla_11091973_p7_1024.jpg).

Figure 5a La Moneda palace, model representing its north facade and the urban environment in the early $19^{\text {th }}$ century (Source: Museo Histórico de Chile).

Figure $5 \mathrm{~b}$ South façade, and Plaza de la Ciudadanía (Undurraga Devés architects), present situation of the building (Source: https://commons.wikimedia.org/wiki/File\%3Alzamiento_de_la_Gran_Bandera_Nacional_(2).jpg).

headquarters of the national mint industry (Guarda 1997). At the time of its erection, its location was part of the urban periphery. During the $19^{\text {th }}$ century, the presidential palace was moved into La Moneda, which offered proper functional conditions as well as monumental features. President Manuel Bulnes took that decision in 1846. Some historians maintain that there were also alleged security reasons: a military headquarters had been located in front of the palace and this was an important safeguard during those agitated political times (UNESCO 2017).

The building certainly needed multiple adaptations to assume its new functions. As anyone could have imagined, the presence of the government in the area turned the originally peripheral location into a new political and administrative centre, while the city expanded around it. New public spaces were generated in its surroundings during the $20^{\text {th }}$ century, which completely changed its urban role. More than one attempt was made to modernise what at the time was considered and old-fashioned colonial building. At least two projects sought to transform the austere colonial premises into an adorned Beaux-Arts monument. But its main transformation occurred around 1930 when the government commissioned architects Smith Solar and Smith Miller to transform the southern area of the building (Figure 3). That refurbishment implied the elimination of the old furnaces of its back area 

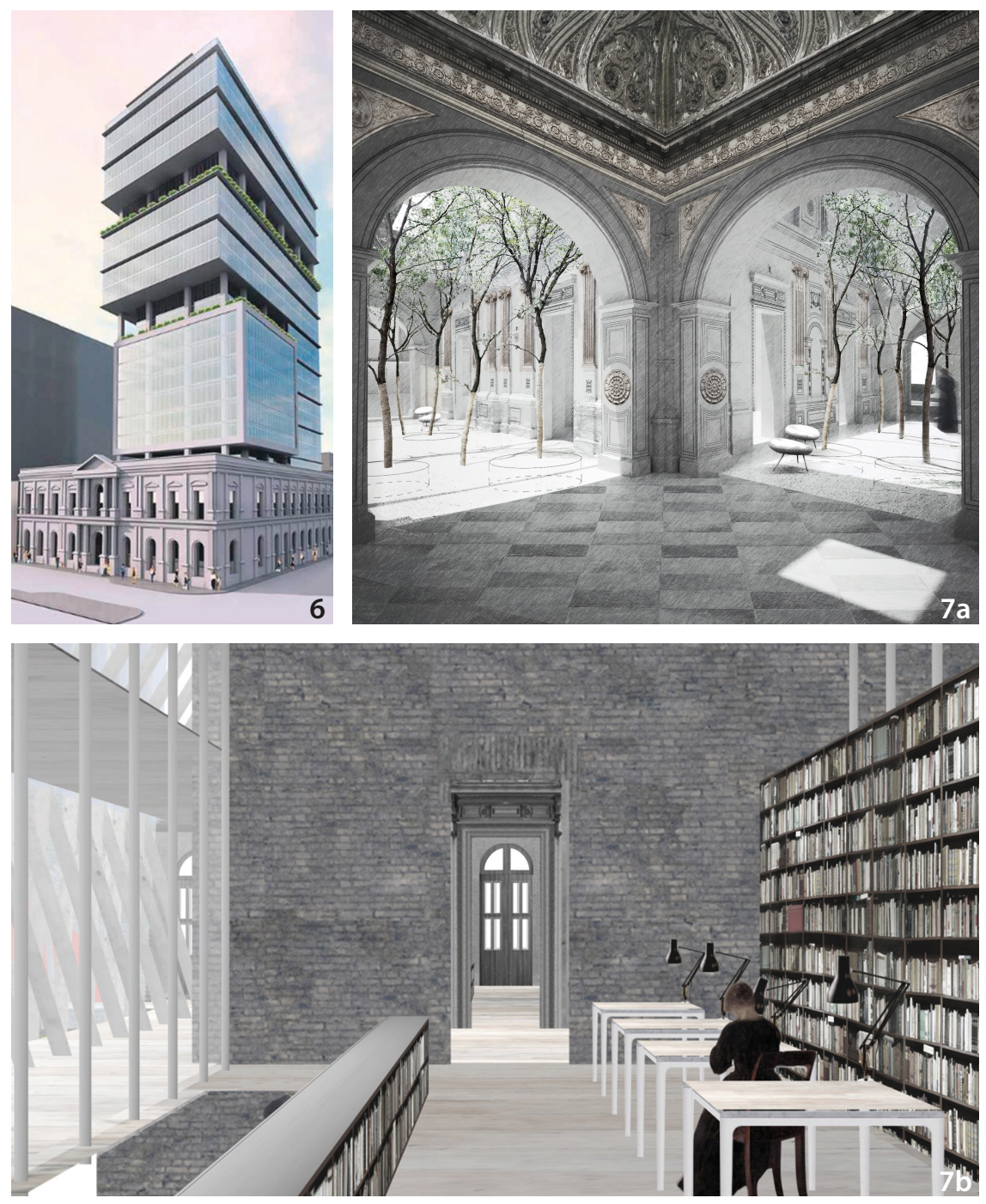

Figure 6 Palacio Pereira, Santiago Chile, 2009, project for a tower surrounded by the Palace's remains approved by the National Council of Monuments (Source: http://www.plataformaarquitectura.cl/cl/02-35658/comite-de-patrimonio-solicita-al-consejo-de-monumentosde-chile-la-no-aprobacion-del-proyectopara-el-palacio-pereira/pereira).

Figure $7 \mathrm{a}$ and $7 \mathrm{~b}$ Cecilia Puga, Alberto Moletto and Paula Velasco, 2014 Palacio Pereira project: restoration and re-use of some of some interior spaces (Source: Cecilia Puga, Alberto Moletto and Paula Velasco).

and the generation of a new patio. But the most impressive of all, was the invention of a new façade towards Alameda Avenue, which had turned to be the main one in the city. The colonial style was selected for that façade, consistently with the new prestige acquired in the meantime by colonial architecture. Currently the great majority of the city population see this new façade as part of the original building.

Decades after, the image of La Moneda bombed and fired by the national air force on the occasion of the military coup against president Salvador Allende, in 1973, went around the world (Figure 4). Once again the building had to be totally refurbished to reassume its political functions. Public spaces in front of its two main façades were also totally remodelled. In synthesis, the isolated building standing today between two modern public spaces is radically different, in shape and use, from that one originally erected (Figure 5a, Figure 5b). Thus, the process of change and adaptation suffered by La Moneda has allowed it to survive and keep its social and urban role.

Another interesting case is provided by Pereira Palace, also located in Santiago de Chile. A late $19^{\text {th }}$ century residential building, designed by the French architect Lucien Henault, it was listed as a national monument in 1981. Both the lack of maintenance and the great diversity of uses had totally deteriorated the original fabric up to turning it into a ruin. The property, in private hands, sought to develop a high rise building there. Thus, the palace was thus totally abandoned and exposed to earthquakes and the rigours of the weather. Different attempts were made by the owners to get approved a project, which could combine the erection of a tower with the permanence of the façade of the old building. In 2009 one of them was even authorised by the Council of National Monuments, but opposed by the municipality (Figure 6). The solution to the conflict came not thanks to a particular design, but to the government decision to buy the property and locate the headquarters of the 


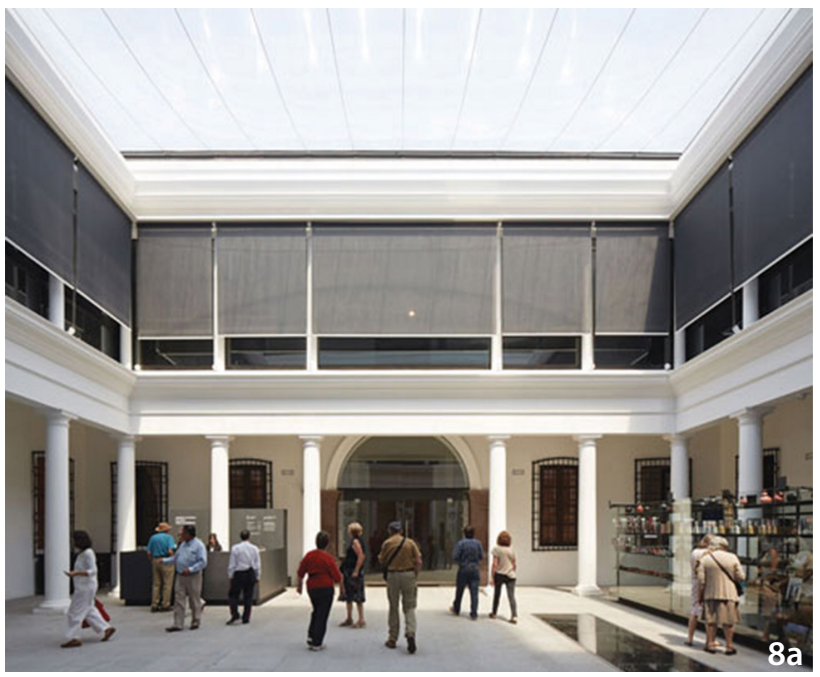

Figure 8a Smiljan Radic, intervention in the Pre-Columbian Museum, Santiago Chile, 2014. The covered patio of the museum (Source: Cristobal Palma).

Figure $\mathbf{8 b}$ The section of the museum (Source: Smiljan Radic).

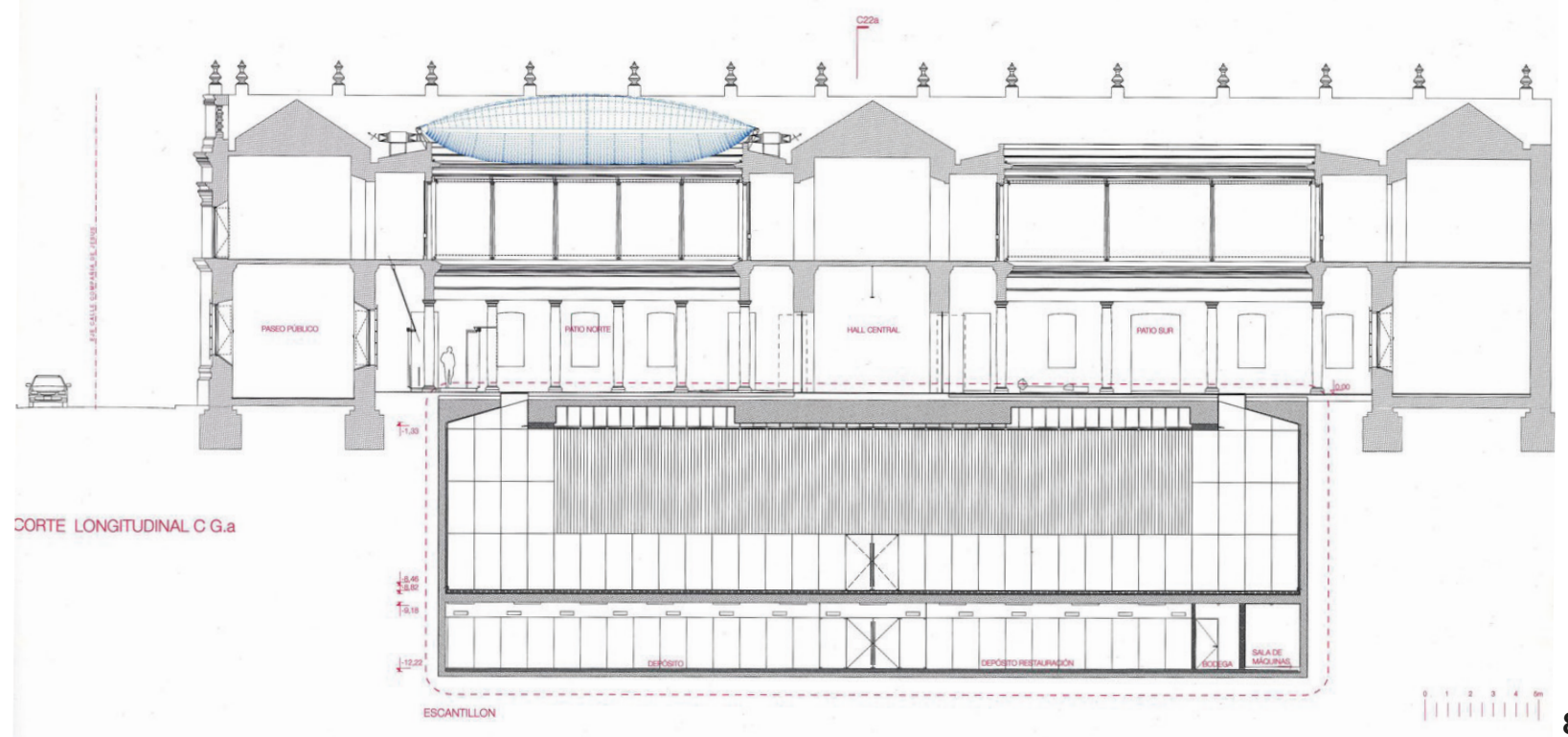

Direction of Archives Libraries and Museums there. A competition was called to add a low-rise building to the monument and restore its remains as a cultural centre (Figure 7a, Figure 7b). The winning entry by Cecilia Puga, Alberto Moletto and Paula Velasco is now under construction and promises to be a significant addition to the urban quality of the neighbourhood (Crispiani 2014; Barreda 2000).

This case teaches us not only on how urban development and monument preservation can clash, but also that finding new uses for old buildings is a key element for their preservation. The new addition is not reminiscent of the $19^{\text {th }}$ century style but seeks to establish a dialogue between new and old forms. The palace itself is being subject to a technically careful restoration, having in mind that it is impossible to bring the building to its original condition. Thus, the traces of the passing of time and even the loss of decoration have been thought as positive factors to articulate new architectural situations. The building will keep its connection to the past but, at once, will be radically transformed. It will gain new life, offering the community the chance to enjoy public facilities in what used to be a private residence.

Smiljan Radic's two recent interventions in Santiago show a similar kind of creative transformations of heritage buildings of a very different kind. In the Pre-Columbian museum, the need for new exhibition areas led to an underground intervention, which radically transformed the structure of the early $19^{\text {th }}$ century building. The covering of one of the patios with a delicate inflatable structure and the renovation of the floors of some public areas gave a contemporary ambiance to the old building (Figure 8a, Figure 8b) (Radic, 2013a). In Nave, a performing centre was allocated in an old house in Yungay neighbourhood. Only its 

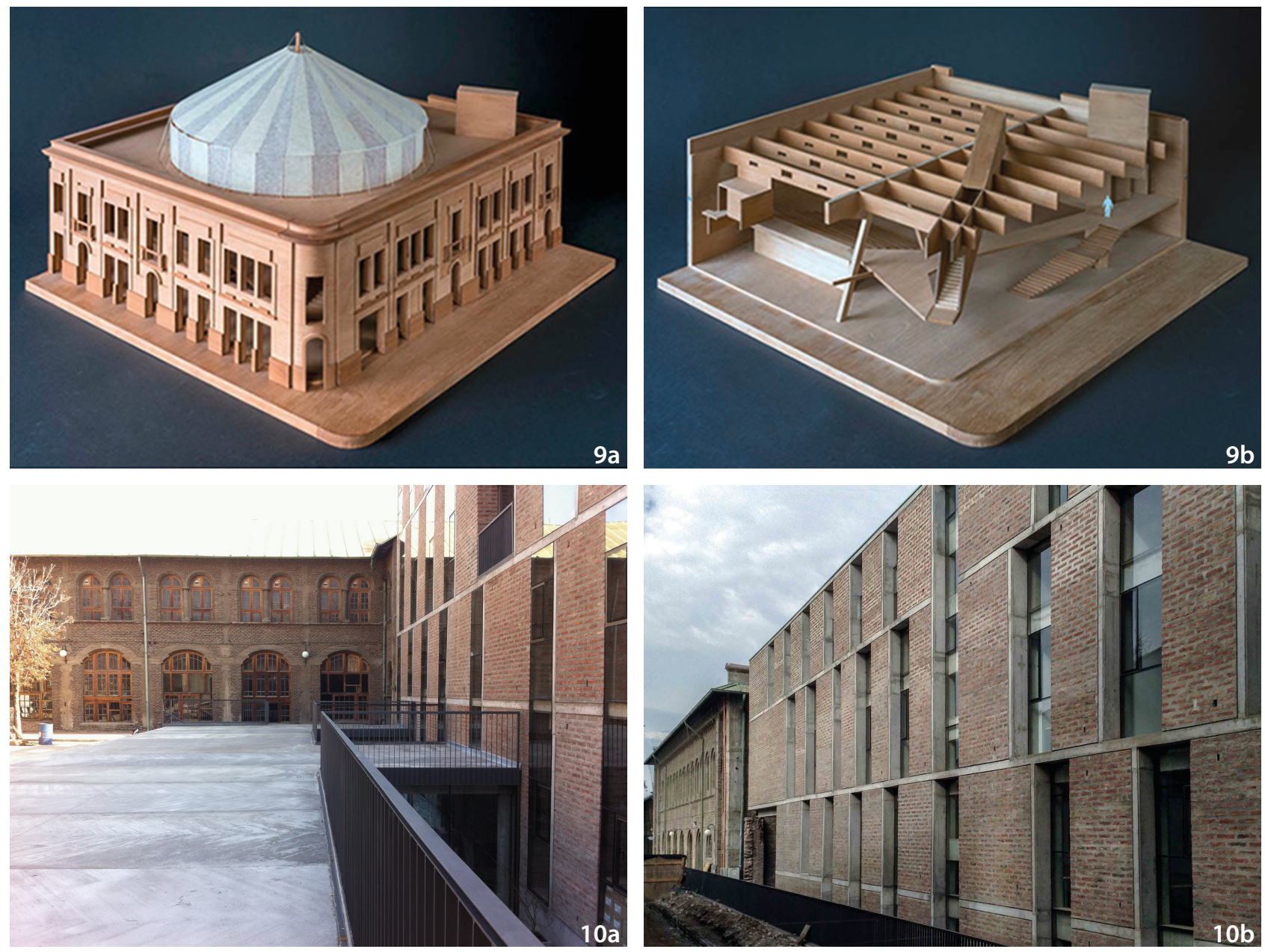

Figure 9a and 9b Smiljan Radic, project for Nave Cultural Centre, Santiago Chile, 2015, models (Source: Smiljan Radic). Figure 10a Fernando Pérez Oyarzun, José Quintanilla and DESE team (Mónica Flores, Luis Lucero and Carolina Rodriguez) Faculty of Arts Academic Building, Campus Oriente, Pontificia Universidad Católica de Chile, 2015. Its southern view, with existing building (Source: José Quintanilla).

Figure 10b The northern view of the Faculty of Arts Academic Building, Campus Oriente, Pontificia Universidad Católica de Chile (Source: Juan Purcell Mena).

façade was kept, generating a new continuous inner space, while maintaining the street traces and continuity. The installation of a circus tent in the upper terrace, endows the neighbourhood with an amazing contemporary performing space (Figure 9a, Figure 9b) (Radic, 2013b).

Extending existing buildings is part of the tradition of architectural craft and has been a way of adapting them to new uses and needs. The Universidad Católica de Chile Campus Oriente (East Campus) is located in what used to be an old school and convent designed in neoRomanesque style. Juan Lyon and Luis Otaegui conceived it in 1927. The original scheme was only partially built. The commission made by the University to architects Fernando Pérez Oyarzun and José Quintanilla was to design a new academic building to the Faculty of Arts. The idea was to complete the original design of one of the cloisters. Thus the location, width and height of the original design were considered as the basis of the new one. The same happened with the dominant materials: brick masonry and reinforced concrete. However, the brief and the functional requirements led to significant changes. To connect the first floor of the old building, accommodating at once the four floors of the new one, this was partially sunken. Openings were located according to new functions and climate conditions. An upper terrace was installed at the roof level and a connection of a new scale was provided towards the northern sports facilities. Thus, in spite of the impression that the building seems to have been there for long and the new wing occupies a position considered in the original design, the cloister has been radically transformed (Figure 10b, Figure 10b) (Pérez Oyarzun and Quintanilla Chala 2017). 


\section{Conclusion}

Denouncing a lack of vitality in the relationship with the built environment inherited from the past, Françoise Choay (2007) has highlighted the fact that the expansion of heritage preservation can be seen as an allegory of a contemporary cultural condition: 'Represented by a labyrinth that conceals the enchanting surface of a mirror, architectonic and urban heritage, together with the conservative behaviours that constitute its cortege, can be interpreted as an allegory of mankind in the beginnings of the $21^{\text {st }}$ century ... ? Perhaps, if we are able to identify what has to be preserved and what needs to be transformed on urban and architectural heritage, we will be able to insufflate new life to them. Transforming heritage is neither ignoring nor inventing it and asks for a deep knowledge about its reality. A careful and proper transformation could thus be a powerful tool to build an urban future that recognises and enjoys a connection with the past.

\section{Notes}

1. For more general information about the case, see https://es.wikipedia.org/wiki/Barrio_Viel

\section{References}

Barreda, Amalia. 2000. "Arquitecturas yuxtapuestas: intervención en el Palacio Pereira: reconstrucción de una manzana fundacional." [Juxtaposed architectures: intervention at the Palacio Pereira: reconstruction of a founding block.] Master thesis. Pontificia Universidad Católica de Chile.

Beiner, Ronald. 2002. "Arendt and Nationalism." In The Cambridge Companion to Hannah Arendt, edited by Dana Villa, 44-62. Cambridge: Cambridge University Press.

Choay, Françoise. 2007. Alegoría del Patrimonio [Allegory of Heritage]. Translated by María Bertrand Suazo. Barcelona: Gustavo Gili.

Crispiani, Alejandro, ed. 2014. Concurso Palacio Pereira: Historia de una Recuperación Patrimonial [Pereira Palace Contest: History of an Asset Recovery]. Santiago: Eds. ARQ.

Graham, Brian, and Peter Howard, eds. 2008. The Ashgate Research Companion to Heritage and Identity. Burlington: Publishing Limited, Hamshire England and Ashgate publishing Company.

Guarda, Gabriel. 1997. El Arquitecto de la Moneda Joaquín
Toesca 1752-1799: una Imagen del Imperio Español en América [The Architect of the Currency Joaquín Toesca 1752-1799: an Image of the Spanish Empire in America]. Santiago: Pontificia Universidad Católica de Chile, Escuela de Arquitectura.

Pérez, Oyarzun, F. and J. Quintanilla Chala. 2017. "Academic Building Faculty of Arts UC." Archdaily. Accessed July 15 2017. http://www.archdaily.com/873258/ academic-building-faculty-of-arts-uc-fernando-perezoyarzun-plus-jose-quintanilla-chala

Radic, Smiljan. 2013a. "Chilean Pre-Columbian Art Extensions." In El Croquis 167, Smiljan Radic 2003-2013 the Games of Opposites, 266-273.

Radic, Smiljan. 2013b. "Yungay Project Performing Arts Hall.” In El Croquis 167, Smiljan Radic 2003-2013 the Games of Opposites, 259-265.

Rodin, Auguste. 1914. Les Cathédrales de France [The Cathedrals of France]. Paris: Librairie Armand Colin.

UNESCO. 2016. Culture Urban Future: Global Report on Culture for Sustainable Urban Development. Paris: UNESCO.

UNESCO. 2017. "La Moneda Palace." UNESCO World Heritage Tentative List. Accessed July 15 2017. http:// whc.unesco.org/en/tentativelists/1195/

Walter, François. 2004. Le figures paysagères de la nation. Territoire et paysage en Europe (16e-20esiècle) [Landscape figures of the nation: territory and landscape in Europe $\left(16^{\text {th }}-20^{\text {th }}\right.$ century) $]$. Paris: Editions EHESS. 